\title{
Developing Student Worksheet for Learning Matrix
}

\author{
Chairil Faif Pasani, Kamaliyah \\ Mathematics Education Study Program, Faculty of Teacher Training and Education \\ Universitas Lambung Mangkurat \\ Banjarmasin, Indonesia \\ chfaifp@unlam.ac.id
}

\begin{abstract}
One of the teaching materials that can improve students' competence in analyzing and solving any problems independently is student worksheet. The use of student worksheet can also help students to comprehend the mathematical concept. This study aimed to develop student worksheet about the properties of determinant of a matrix. This study was a development research with formative evaluation type. The data in the research were the result of expert review, one-to-one evaluation, small group evaluation, and field test. The research subjects were students who programmed Matrix in Mathematics Education Study Program, Universitas Lambung Mangkurat. From the analysis, it can be concluded that the research has resulted in the student worksheet for learning Matrix. At the expert review stage, two experts evaluated the content and instructional design. The worksheet was tried out toward students with different mathematical abilities at one-to-one and small group evaluation. At the field test stage, 32 students used the worksheet in groups to learn the properties of determinant of a matrix.
\end{abstract}

\section{Keywords-Development, Matrix, Worksheet}

\section{INTRODUCTION}

Science and technology develop faster so that human resources that are able to compete globally are necessary. In the era of globalization, Indonesian students should have competence to compete with other students from various countries. The improvement of Indonesian competence and competitiveness can be done by using student-centered instruction in mathematics that helps students develop critical thinking through exploring structured problems.

Students are expected to understand the materials of the mathematics learning comprehensively and holistically that can increase students' independence and creativity in mathematics [5]. One of the teaching materials that can be used in studentcentered instruction and improve students' competence in analyzing and solving any problems independently is student worksheet [2].

The use of student worksheet can help students to comprehend the mathematical concept [5]. In addition, student worksheet also can help students to be active in learning process, develop student confidence, increase learning motivation and eagerness, and teach student to use time in effective way. These benefits show that the student worksheet gives considerable influence in teaching learning process.

The development of student worksheet should meet some requirements i.e. validity, practicality, and effectiveness [4].
Validity refers to the extent that the design of the worksheet should include "state of the art knowledge" (content validity). Practicality refers to the extent that users (students) and other experts consider the worksheet as appealing and usable in normal conditions. Effectiveness refers to the extent that the experiences and outcomes from the worksheet are consistent with the learning objectives.

This study aimed to develop student worksheet about the determinant properties of a matrix. Student worksheet is used to teach Matrix course with a series of questions as an introduction to reinvent the properties of determinant of a square matrix. Students were also asked to give a proof for their answer.

\section{METHOD}

The study was conducted in even semester of the academic year 2016/2017 in Mathematics Education Study Program, Universitas Lambung Mangkurat. Development research with formative evaluation type was used in the study as a method [1] which includes expert review, one-to-one evaluation, small group evaluation, and field test. The sequence of formative evaluation is as follows (Fig. 1).

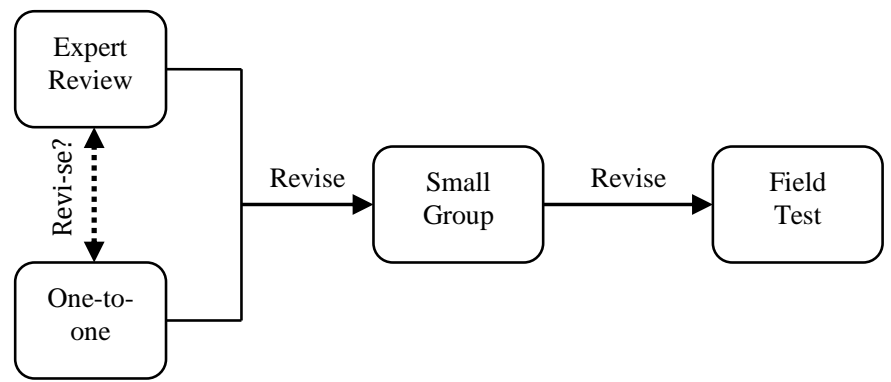

Fig. 1. General sequence of formative evaluation types

Data collection techniques used in this study are interview to find out the qualitative validity of the content and construct, determine students' suggestions and comments; documentations to determine the practicality of worksheet; and test. The research subjects were students who programmed Matrix in Mathematics Education Study Program, Universitas Lambung Mangkurat.

\section{RESULTS AND DISCUSSION}

Student worksheet which has been developed refers to the following learning outcomes: (1) differentiating the characteristic of matrix that has determinant, (2) determining 
the determinant of matrix order $2 \times 2$, (3) determining the determinant of matrix order $3 \times 3$, (4) using properties of determinant to solve the problem, and (5) creating matrix which has determinant equal to 0 . The properties of determinant of matrix that have to be reinvented by students are $(|A|$ and $|B|$ are determinant of matrix $A$ and matrix $B$ respectively) as follows: (1) if every element of a row (column) of a square matrix $\mathrm{A}$ is zero then $|A|=0$, (2) $|A|=\left|A^{\prime}\right|$, (3) if every element of a row (column) of a determinant $|A|$ is multiplied by scalar $k$, the determinant is multiplied by $k$, (4) if $B$ is obtained from $A$ by interchanging any two adjacent rows (columns) then $|B|=-|A|$, (5) if $B$ is obtained from $A$ by interchanging any two of its rows (columns) then $|B|=-|A|$, (6) if $B$ is obtained from $A$ by carrying its $\mathrm{i}^{\text {th }}$ row (column) over $p$ rows (columns) then $|B|=(-1)^{\mathrm{p}}|A|$, (7) if two rows (columns) of $A$ are identical then $|A|=0,(8)$ if every element of the $\mathrm{i}^{\text {th }}$ row (column) of $A$ is the sum of $p$ terms the $|A|$ can be expressed as the sum of $p$ determinants, (9) if $B$ is obtained from $A$ by adding to the elements of its $i^{\text {th }}$ row (column), a scalar multiple of the corresponding elements of another row (column), then $|B|=|A|$ [Ayres].

\section{A. Expert Review}

At this stage, two experts reviewed the draft of the worksheet which focused on the content and construct validity. The investigation of the content and construct validity was focused on the following issues:

- Does the content include the topic taught in Matrix?

- Does the content reflect the student-center instruction?

- Is the content sequenced properly?

- Are the learning outcomes stated clearly?

- Is the content well chosen to meet the learning outcomes?

- Is the duration (50 minutes) mentioned in the worksheet enough?

The improvements were made on the worksheet based on the results of the interviews and discussions with the experts. The experts suggested fixing the font style, improving the mathematical term which was mistyped, and reconsidering the duration for students to work using the worksheet (Fig. 2).

\section{B. One-to-one Evaluation}

At one-to-one evaluation, the worksheet which developed was tested to three students with different mathematical abilities, i.e. high, medium, and low. The procedure was same for each student although it was performed at different times. The researchers met each student and involved them in an informal conversation. One-to-one evaluation focused on clarity and ease of use of the questions that were developed, as well as the interest of students to such questions. Generally, the students gave positive comments for the worksheet and they could understand the questions except for question 3 because there is a mistyping. One of the students' suggestions is shown in Fig. 2. After the expert review and one-to-one evaluation, the worksheet was revised to be used in small group.

Soal nomor 2: Perintah kesimpulan mungkin bisa lebih detail lagi/diberi perintah berdasarkan sifat - sifat dari determinan.

Fig. 2. One of the student's comment

\section{Small Group Evaluation}

At this stage, the researchers acted as observers in the learning in which the worksheet was used by three students working in group. The students were required to solve nine problems and provide suggestions/comments on worksheet that has been done. One of the problem solved is shown in Fig. 3.

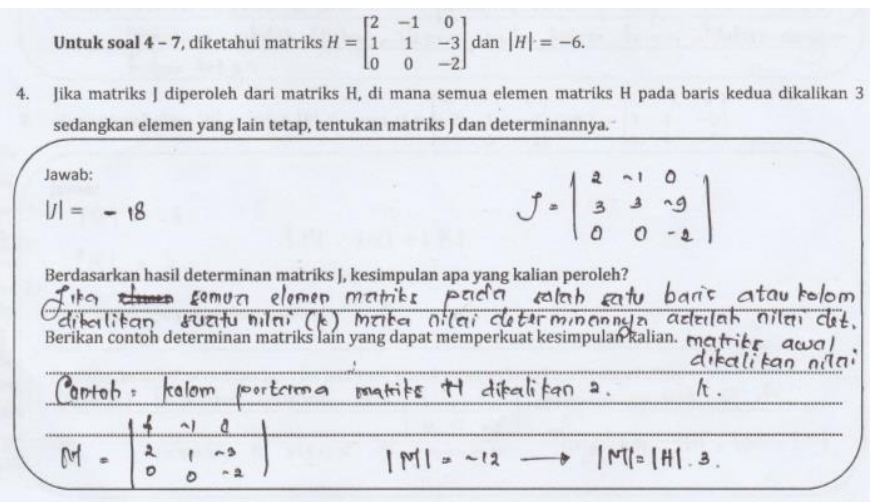

Fig. 3. Group works for the fourth question

From 9 questions, the group of students just could solve seven questions in 50 minutes. Based on the result, the researchers tried to make questions simpler by deleting the question 'Proof your answer by using other matrices' (Fig. 4.).

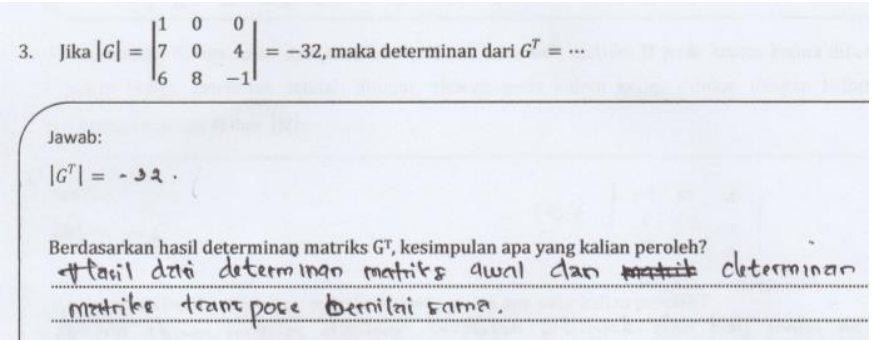

Fig. 4. Group works for the fourth question

The practicality of the worksheet was that the students can appeal and use it in normal conditions. This was investigated by carrying out the observation while a group of students was solving the 9 problems in the worksheet in 50 minutes. Eventhough the group could not solve all the problems in 50 minutes, it can be said that in general the worksheet can be used in normal condition with some small revisions.

\section{Field Test}

Field tests conducted in Matrix class that consisted of 32 students and the students were divided into 8 groups. The groups were given 50 minutes to work on nine questions in 100 minutes learning. After the students finished the worksheet, three groups presented their work and the teacher gave additional comment to conclude the properties of determinant of matrix together with students. At the end of the learning session, the students did the test individually about the determinant of matrix.

The aspects of effectiveness that were investigated in this stage involved: (1) Did the students like learning using worksheet? (2) Was their time spent well? (3) Did the 
worksheet affect students' understanding, activity, creativity, and, motivation?

The issues were evaluated by interviewing 7 students. They were asked to mention their opinion about the worksheet, the problems they had solved, and the way the teaching and learning process had been conducted. All students said that they like the use of worksheet in the learning and like learning in group.

The students' understanding on the properties of determinant matrix was evaluated by giving a test consisting of five questions. The result of the test was satisfying enough in which the average of students' achievement was 78.75 in scale 1-100. The following example shows the answer of the student on the test for questions number 1 to 3 (Fig. 5).

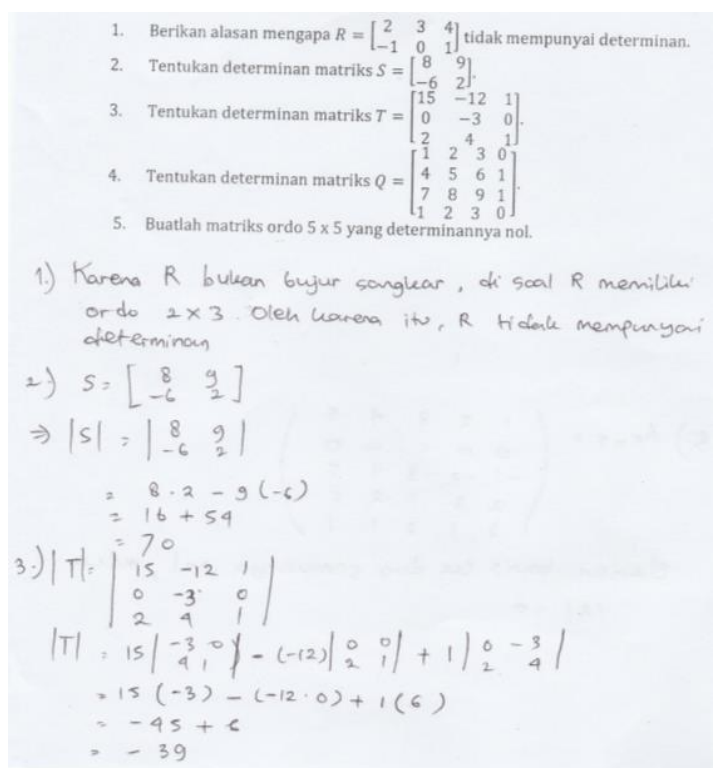

Fig. 5. Students' answer on the individual test for question 1 to 3

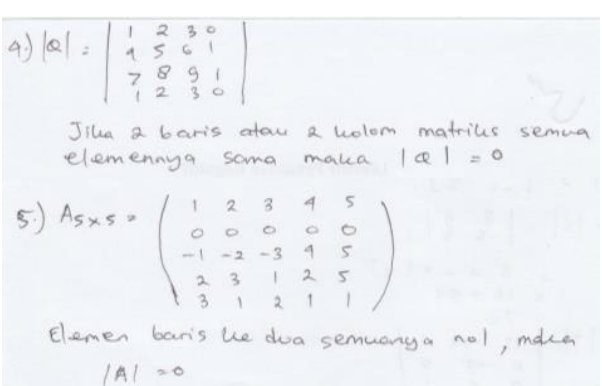

Fig. 6. Students' answer on the individual test for question 4 and 5

The evaluation of the effectiveness of the student worksheet was conducted in a rather informal way.

\section{CONCLUSIONS}

From the study, it can be concluded that the research has resulted in student worksheet for learning Matrix. At the expert review stage, two experts evaluated the content and construct validity. The worksheet was tried out toward students with different mathematical abilities at one-to-one and small group evaluation. At the field test stage, 32 students used the worksheet in groups to learn the properties of determinant of a matrix.

\section{REFERENCES}

[1] M. Tessmer, "Planning and conductingm formative evaluations," Philadelphia: Kogan Page, 1993.

[2] T. J. Newby, D. A. Stepich, J. D. Lehman, J.D. Russell, "Instructional Technology for Teaching and Learning, Designing Instruction, Integrating Computers, and Using Media (second edition)," New Jersey: Prentice-Hall, Inc, 2000.

[3] F. Ayres, "Theory and Problems of Matrices," New York: Schaum Publishing, 1962

[4] A. Fauzan, "Applying Realistic Mathematics Educatiom (RME) in Teaching Geometry in Indonesian Primary School," Doctoral dissertation. Enschede: University of Twente., 2002.

[5] A. Dhoruri, R. Rosnawati, A. Wijaya, "Developing Mathematics-Students Worksheet Based on Realistic Approach for Junior High School in Bilingual Program," Proceeding International Seminar and the Fourth National Conference on Mathematics Education, Yogyakarta State University, 2011.

[6] E. Rohaeti, "Pengembangan lembar kerja siswa (LKS) mata pelajaran sains kimia untuk SMP," Inovasi Pendidikan Jilid 10, No. 1, Mei 2009.

[7] E. Widjajanti, "Kualitas Lembar Kerja Siswa," Pelatihan Penyusunan LKS Mata Pelajaran Kimia Berdasarkan KTSP, Universitas Negeri Yogyakarta, Agustus 2008. 